\title{
Proceraea janetae sp. nov. (Annelida, Syllidae, Autolytinae), a scleractinian coral feeder from Grand Cayman Island
}

\author{
DANIEL MARTIN ${ }^{1}$, JOÃO GIL ${ }^{1}$, CYNTHIA ABGARIAN ${ }^{2,3}$, ESSI EVANS ${ }^{4,5}$, EVERETT M. TURNER JR ${ }^{4,5}$ \\ AND ARNE NYGREN ${ }^{6}$ \\ ${ }^{1}$ Centre d'Estudis Avançats de Blanes (CEAB-CSIC), Carrer d'Accés a la Cala Sant Francesc 14, 1730o Blanes, Girona, Catalunya, \\ Spain, ${ }^{2} 5420$ Meadowcrest Dr, Ann Arbor, Michigan 48105, USA, ${ }^{3} 228$ Raleigh Quay \#A9, West Bay, Grand Cayman, British West \\ Indies, ${ }^{4} 64$ Scugog Street, Bowmanville, Ontario $\mathrm{L}_{1} \mathrm{C}_{3} \mathrm{~J}_{1}$, Canada, ${ }^{5}$ Lighthouse Point Condos, 571 Northwest Point Road, West Bay, \\ Grand Cayman, British West Indies, ${ }^{6}$ Göteborg University, Sjöfartsmuseet Akvariet, Karl Johansgatan 1-3, 41459 Göteborg, Sweden
}

\begin{abstract}
We have found a new species of Autolytinae (Annelida, Syllidae), Proceraea janetae, feeding on the scleractinian coral Montastrea cavernosa in coral reefs surrounding the Grand Cayman Island (Cayman Islands, British West Indies). The new species has a characteristic combination of transversal brown markings on the segmental margins and diffuse white middorsal transverse bars, together with a diffuse white mid-dorsal longitudinal band. Antennae are brown, tentacular cirri are pale, the first dorsal cirri are white with pale base; the second dorsal cirri are pale, and the remaining dorsal cirri are alternately long, bright yellow-orange with brownish tips and short, entirely brown. The trepan has 18 tricuspid teeth in one ring. There are 9 teeth with all cuspids equally long and 9 with a longer median cuspid, arranged in an alternating pattern. We describe and illustrate the feeding behaviour of the new species, which appears to be closer to parasitism rather than to specialized predation. Proceraea janetae sp. nov. is the second polychaete, and the first syllid, known to feed on scleractinian corals.
\end{abstract}

Keywords: Proceraea, Autolytinae, Syllidae, Polychaeta, feeding behaviour, scleractinian coral, Grand Cayman Island, Caribbean, new species

Submitted 14 May 2014; accepted 29 August 2014; first published online 9 October 2014

\section{INTRDDUCTION}

Autolytinae syllids are small free-living polychaetes, ranging from $1-60 \mathrm{~mm}$ long and from $0.1-1.2 \mathrm{~mm}$ wide. They are distributed worldwide and inhabit shallow waters, mostly restricted to the continental shelf. They constitute a phylogenetically well-delineated group of syllids (Aguado \& San Martín, 2009), which are characterized by a sinuous pharynx, absence of ventral cirri, presence of simple bayonet-type dorsal chaetae, and reproduction with dimorphic sexes (Franke, 1999; Nygren \& Sundberg, 2003; Nygren, 2004). Following Nygren (2004) and Nygren \& Pleijel (2007), Autolytinae comprises 173 nominal species, of which more than 100 are considered to be valid. These are divided into 12 currently recognized genera (Nygren \& Pleijel, 2007; Nygren et al., 2010). Among them, Proceraea Ehlers, 1864 contains 27 species (Nygren, 2004; Nygren et al., 2010).

Autolytines often live in a more or less intimate association with colonial organisms on which they supposedly feed, such as cnidarians (usually hydroids) or bryozoans, but they are also known to live inside sponges or among algal beds or calcareous

Corresponding author:

D. Martin

Email: dani@ceab.cisc.es crusts (Okada, 1928; Hamond, 1969; Fauchald \& Jumars, 1979; Genzano \& San Martín, 2002; Nygren, 2004; Nygren \& Pleijel, 2007). Among those associated with cnidarians, only a few are sufficiently known to be defined as true symbionts, and most of these are parasites (Martin \& Britayev, 1998). For instance, some may induce galls on their hydrocoral hosts (Wright \& Woodwick, 1977) or modify the theca of polyps of their hydroid host in order to live inside it (Britayev et al., 1998; Britayev \& San Martín, 2001). However, they are more commonly found living inside thin, semi-hyaline tubes, either made in association with the host or secreted by themselves and attached directly to the colonies on which they prey (Gidholm, 1967; Fischer et al., 1992; Genzano \& San Martín, 2002). In some cases, these associations appear to be obligate in that the worms are always found living together with the same host species (Nygren \& Pleijel, 2010).

During a series of diving expeditions carried out on the coral reefs surrounding Grand Cayman (Cayman Islands, British West Indies), we repeatedly observed, photographed and filmed the brightly coloured specimens of an autolytine polychaete that was moving on the surface of the Great Star coral, Montastraea cavernosa Linnaeus, 1767 (Figure 1).

In this paper, we describe these specimens as a new species within the genus Proceraea, based on morphological features. The observations in situ also allow us to describe the behaviour of the polychaete and the relationship with its scleractinian coral prey. 

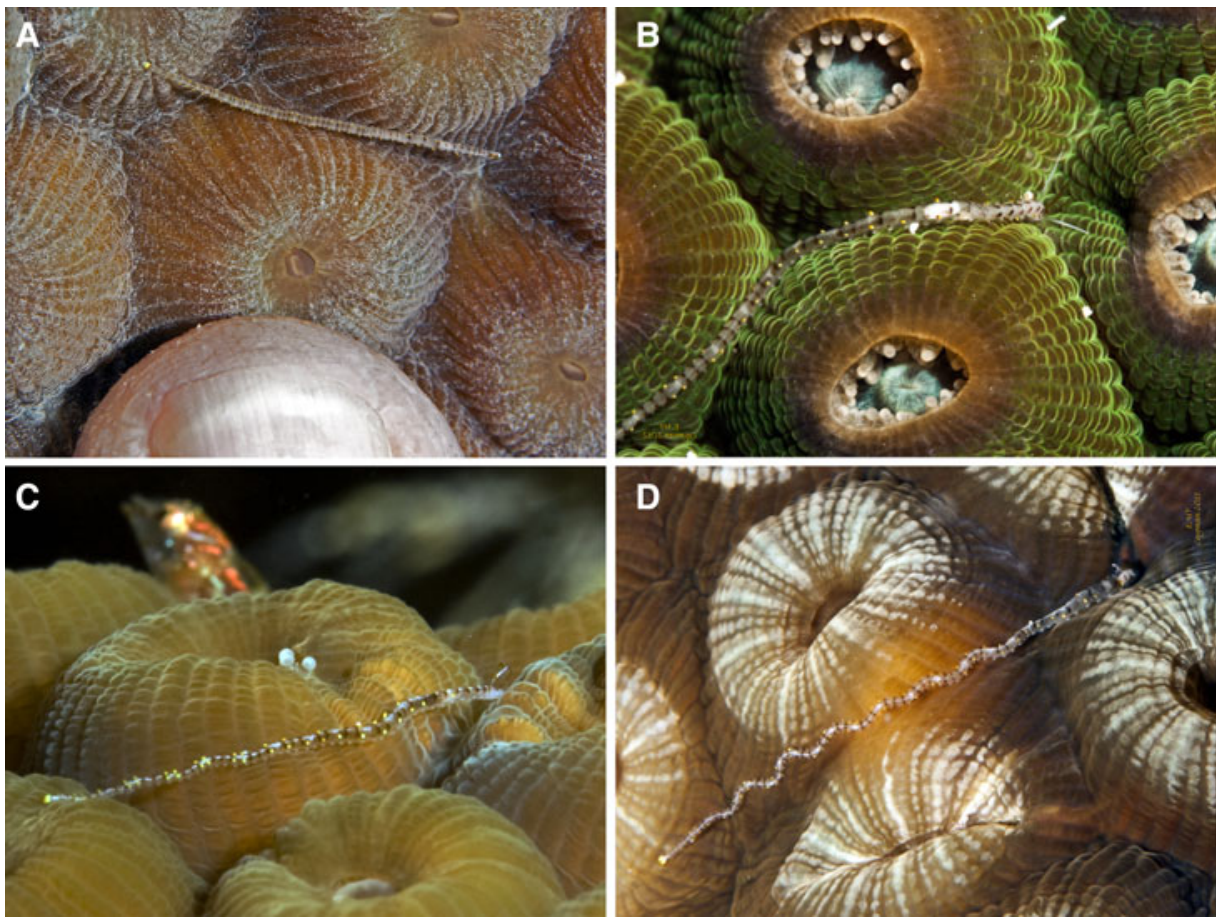

Fig. 1. Proceraea janetae sp. nov. In situ macro-photographs. (A-D) Living specimens crawling on Montastrea cavernosa. Finger tip on A helps to indicate approximate worm size.

\section{MATERIALS AND METHDDS}

We observed and collected the worms while scuba-diving from North West Point, Grand Cayman (Cayman Islands, British West Indies). Underwater photos were done with housed Canon DSLR cameras by CA, EE and EMT. Specimens were collected while diving on 13 February 2013, from 9:30 am to 2:30 pm, and on 24 February, from 9:00 am to $11: 30$ am. Depths ranged from 10 to $18 \mathrm{~m}$ and water temperature was $25-25.5^{\circ} \mathrm{C}$.

We collected all worms on $M$. cavernosa by shining the bright flashes of an underwater light on them, and then creating a slow water movement above them via finger flicking in order to remove them from the surface of the coral. Once floating, we gently collected the worms with small squares of green scour pads on which they could land softly. The pads with the worms were then placed into a screw-top jar filled with seawater and brought back to shore. Once on shore, some specimens left the scour pads on their own accord, some were gently persuaded to leave the pads, and some were intricately embedded within the pad fibres and could not be removed from the pads without damage. All specimens were then relaxed by storing in a freezer for a brief period of time before being transferred either into 150 proof, clear, Jamaican rum (10 specimens), as $100 \%$ ethanol was unavailable on Grand Cayman, or into a $10 \%$ phosphate buffered formalin seawater solution (4 specimens). Unfortunately, the efforts to obtain DNA from rum-preserved worms were unsuccessful.

The type series of the new species are deposited in the Museo Nacional de Ciencias Naturales of Madrid, Spain (MNCN), and the Museu Nacional de História Natural e da Ciência, Lisbon, Portugal (MUHNAC).
SYSTEMATICS

Phylum ANNELIDA Lamarck, 1809

Subclass ERRANTIA Audouin \& Milne-Edwards, 1832

Order PHYLLODOCIDA Dales, 1962 Suborder NEREIDIFORMIA

Family SYLLIDAE Grube, 1850

Subfamily AUTOLYTINAE Langerhans, 1879

Tribe PROCERINI Nygren, 2004

Genus Proceraea Ehlers, 1864

Proceraea janetae sp. nov.

(Figures 1-8)

TYPE MATERIAL

Holotype: MNCN 16.01/15563. North West Point, Grand Cayman Island $\left(19^{\circ} 22^{\prime} \mathrm{N} 81^{\circ} 24.5^{\prime} \mathrm{W}\right)$ preserved in rum and then transferred to ethanol.

Paratypes: MNCN 16.01/15564, 10 specimens, same location, preserved in rum and then transferred to ethanol; MNCN 16.01/15565, 3 specimens, same location, preserved in formalin and then transferred to ethanol; MNCN 16.01/ 15566,1 specimen, same location, fixed and preserved in formalin, mounted for SEM; MUHNAC MB29-000340, 2 specimens, same location, preserved in rum and then transferred to ethanol.

\section{DIAGNOSIS}

Proceraea with bright yellow-orange, swollen, dorsal cirri alternating with thinner, shorter, brown dorsal cirri, and trepan with 18 tricuspid teeth, alternating in one ring. 

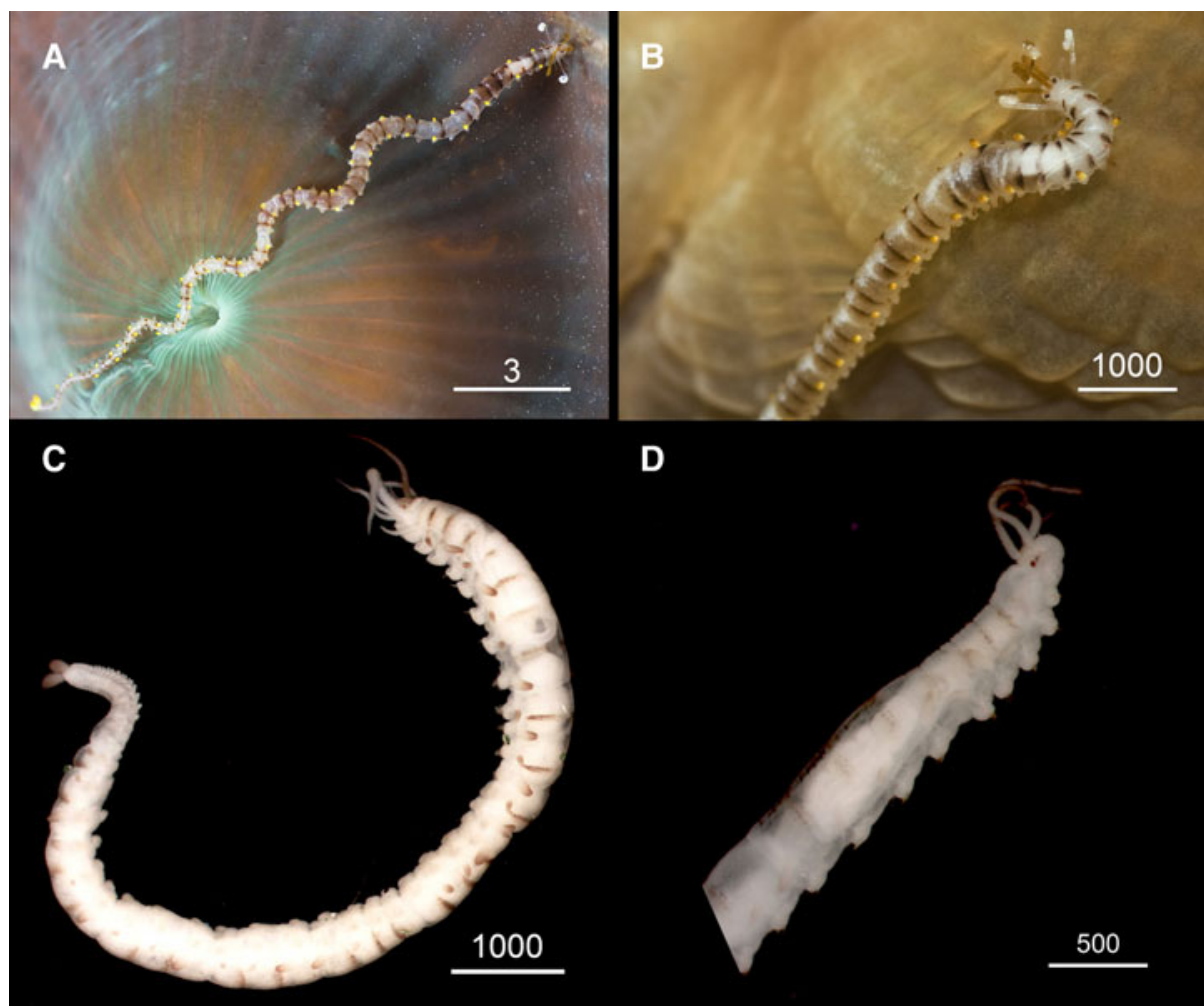

D

Fig. 2. Proceraea janetae sp. nov. In situ macro-photograps of living specimens (A) Whole worm. (B) Detail of the anterior end. Stereomicroscope micrographs of preserved specimens. (C) Holotype MNCN 16.01/15563 whole body. (D) Paratype MNCN 16.01/15564 anterior end. Scale bars are mm (A) and $\mu \mathrm{m}$ (B-D).

\section{DESCRIPTION}

Length up to $\sim 25 \mathrm{~mm}$ for 95 chaetigers, width at level of proventricle, excluding parapodial lobes, $\sim 0.5 \mathrm{~mm}$. Live specimens with characteristic pigmentation pattern (Figures $1 \mathrm{~A}-$ D \& 2 A, B). Brown lateral intersegmental patches connected dorsally on median and posterior chaetigers forming medially narrowed, transverse bands. Brown markings on every segmental border on chaetigers $1-9$, on every second segmental border on chaetigers $10-13$, in groups of two succeeding segmental borders with one segmental border lacking brown markings in between on chaetigers 14-22, and also from chaetiger 43 to posterior-most end, and finally in groups of three succeeding segmental borders, with one segmental border lacking brown markings in between, on chaetigers $23-42$. Thus, brown band pattern from anterior end to pygidium consisting of a first group of 8 consecutive bands (or pairs of lateral patches), then 2 bands at some distance from each other, then 3 groups of 2 close bands, 4 groups of 3 close bands, and finally groups of 2 bands to posterior-most end. More or less diffuse white mid-dorsal transverse bars or bands on every segment in anterior chaetigers, coinciding with brown intersegmental markings, but placed anteriorly. In median and posterior chaetigers, white bands/bars most distinct in areas lacking brown markings. White pigmentation also often scattered mid-dorsally, forming diffuse mid-dorsal longitudinal band. White pigmentation variable, and transverse bars/bands sometimes absent, except in anterior-most chaetigers. Median and lateral antennae brown; first dorsal cirri white, often arranged in spiral, with most proximal region pale; tentacular cirri and second dorsal cirri long, pale; remaining dorsal cirri shorter, alternating long, bright yellow-orange with brownish tips and short, entirely brown ones; anal cirri bright yellow-orange with brownish tip, slightly bigger than dorsal cirri. Preserved specimens whitish, showing brown markings on segments and brown pigmentation on antennae and dorsal and anal cirri (Figure $2 \mathrm{C}, \mathrm{D}$ ).

Body shape, excluding parapodial lobes, cylindrical in transection, ventrally flattened. Body long and slender, fairly constant in width, with slowly tapering posterior end. Nuchal epaulettes ciliated. Prostomium rounded, rectangular (Figure 3A). Four eyes with lenses, anterior pair larger, confluent in dorsal view; eye spots absent (Figure $3 \mathrm{~A}$ ). Palps in dorsal view projecting about half of prostomial length, fused. Nuchal epaulettes extending to beginning of chaetiger 1 . Prostomium with three antennae; median antenna inserted medially on prostomium, lateral antennae on anterior margin. Median antenna reaching chaetiger 7-9, lateral antennae about half as long as median antenna. Tentacular cirri two pairs. Dorsal tentacular cirri about $1 / 2$ as long as median antenna, ventral tentacular cirri about $1 / 3$ as long as dorsal tentacular cirri.

Dorsal cirri from chaetiger 1, alternating in orientation, where $\mathrm{D}=$ cirri pointing down, $\mathrm{U}=$ cirri pointing up and $\mathrm{I}=$ somewhere in between: U DDU DU DDU, followed by nine DU-groups, four DDUU-groups, one DDU-group and various combinations of DDU, DUU or DIU-groups until pygidium. Posterior to chaetiger 30 (but also rarely in more anterior chaetigers) sometimes irregular, with one cirri pointing up and another pointing down on same segment. First dorsal cirri about as long as median antenna, second dorsal cirri as long as ventral tentacular cirri. From chaetiger 3, cirri alternate in length, long cirri (pointing up) $1 / 4-1 / 3$ as long as body width, short cirri (pointing down) $1 / 5-1 / 4$ as long as body width (Figure $3 \mathrm{~B}$ ), anal cirri as long as $2 / 3$ of body width at level of proventricle. 


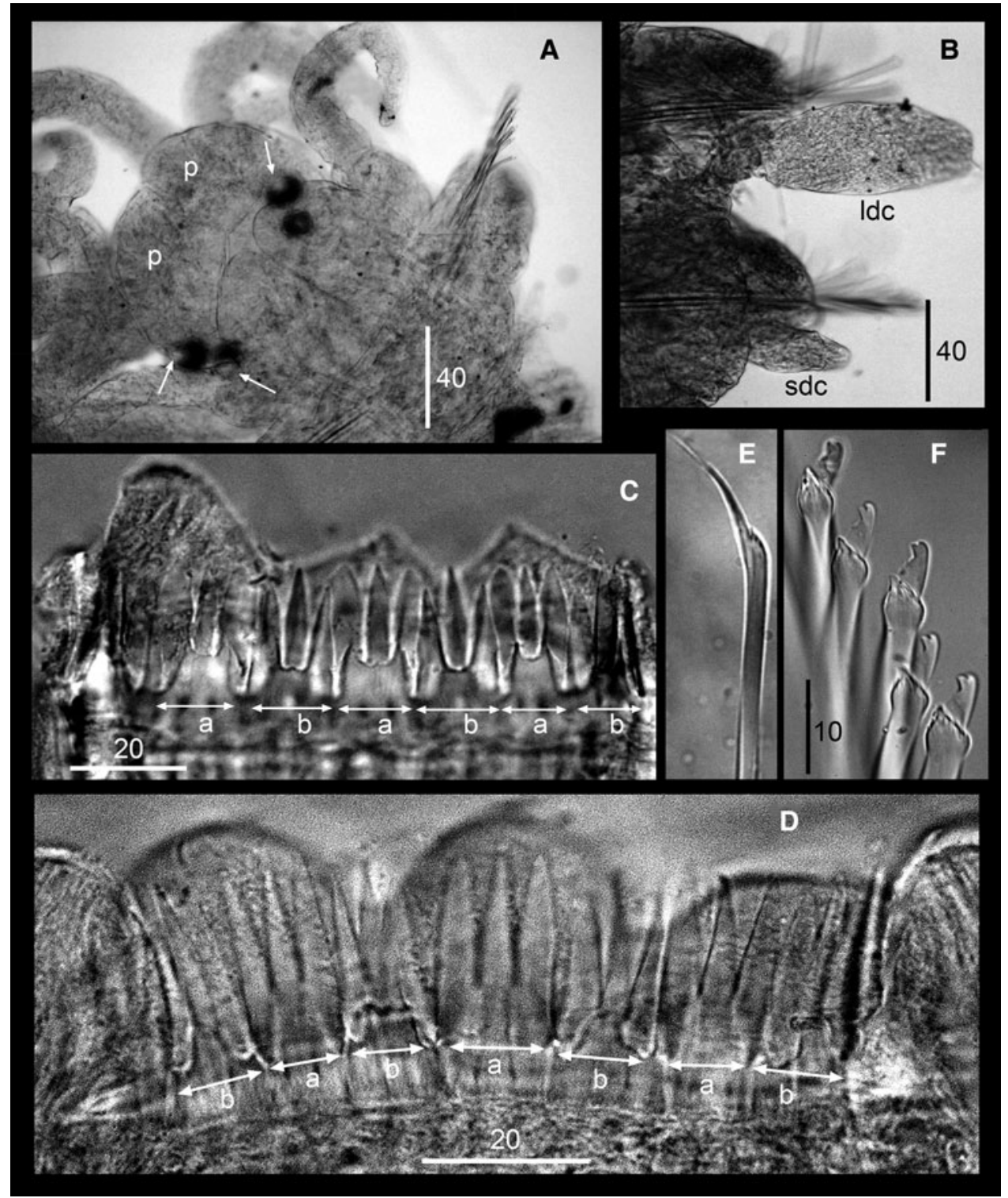

Fig. 3. Proceraea janetae sp. nov. Binocular micrographs of paratypes MNCN 16.01/15564 (A-C, E) and MNCN 16.01/15563 (D, F). (A) Anterior end, ventral view, arrows pointing the eye lenses. (B) Parapodium. (C, D) Trepan. (E) Bayonet chaeta. (F) Compound chaetae. p, palps; ldc, long dorsal cirri; sdc, short dorsal cirri; a, teeth with equally long cusps; b, teeth two short lateral and one long central cusps. Scale bars are $\mu \mathrm{m}$.

Cirrophores on tentacular segment and first dorsal cirri, otherwise absent. Antennae, tentacular cirri, first and second dorsal cirri, and short dorsal cirri cylindrical; long dorsal cirri swollen, egg shaped; anal cirri swollen, with pointed end. Parapodial lobes small, rounded. Aciculae 1-3 in anterior chaetigers, $1-2$ in median and posterior chaetigers. Chaetal fascicle with 9-12 compound chaetae in anterior chaetigers, 6-10 in median and posterior chaetigers. Compound chaetae in anterior 10-15 chaetigers with small distal tooth, thereafter becoming larger but still smaller than subdistal one; blade serrated; shafts with swollen tips having numerous spines (Figure $4 \mathrm{~B}$ ). Single, thick, distally denticulated bayonet chaetae on each parapodium of posterior chaetigers (Figures $3 \mathrm{E} \& 4 \mathrm{~A}$ ). Pharynx with single, long sinuation along the side of the proventricle. Trepan at level of chaetiger 2, with 18 tricuspid teeth in one ring, alternating with 9 tricuspid teeth with all cusps equally long, with 9 tricuspid teeth with median cusp longer (Figures ${ }_{3} \mathrm{C}, \mathrm{D} \&{ }_{4} \mathrm{C}, \mathrm{D}$ ). Basal ring present, infradental spines not possible to assess. Proventricle as long as 2-3 segments, at level of chaetigers $6-9$, with $40-45$ rows of muscle cells.

Reproduction unknown.

\section{ETYMOLOGY}

The species epithet is dedicated to Janet Kramer Kaufman (Louisville, Kentucky, USA), beloved aunt of CA, as a recognition for instilling a sense of discovery, adventure and exploration, and as a special gift on the occasion of her 9oth birthday.

\section{HABITAT}

Proceraea janetae sp. nov. lives in shallow tropical waters (around $25^{\circ} \mathrm{C}$ ) down to $18 \mathrm{~m}$ depth, on coral reefs with Montastrea cavernosa. 


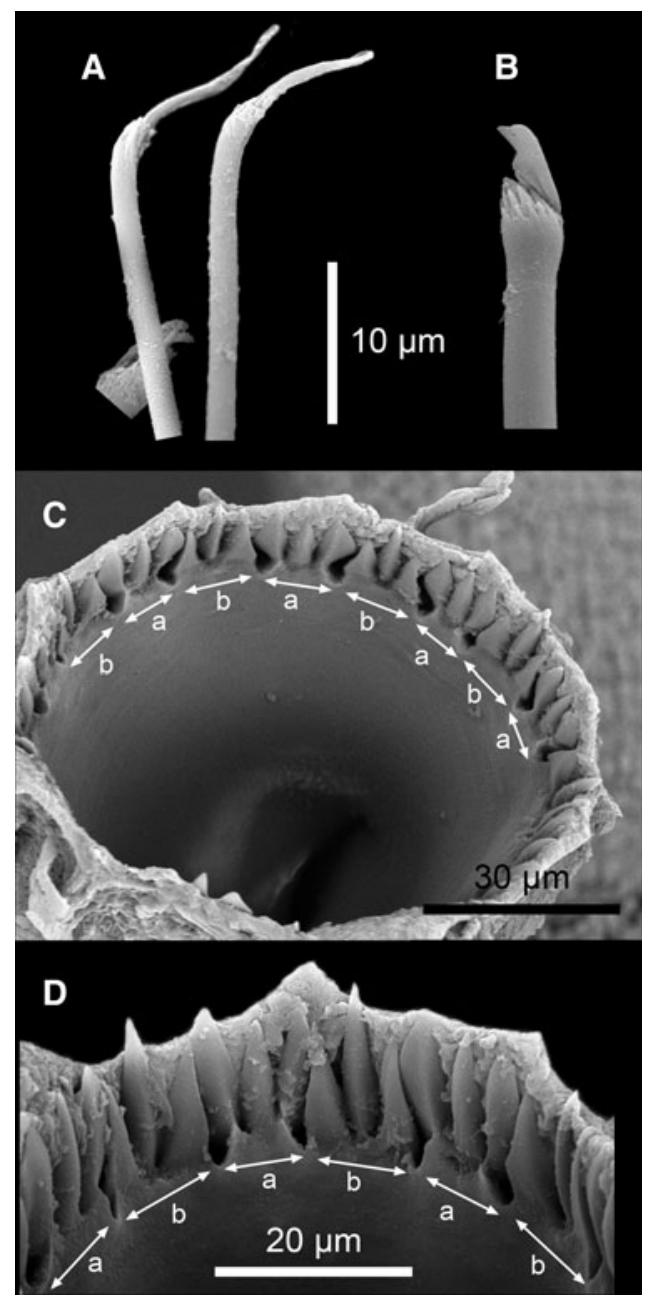

Fig. 4. Proceraea janetae sp. nov. SEM micrographs of Paratype MNCN 16.01/ 15566. (A) Bayonet chaetae and blade of a compound chaeta. (B) Compound chaeta. (C) Trepan, upper view. (D) Trepan, lateral view. a, teeth with equally long cuspids; $b$, teeth two short lateral and one long central cuspids.

\section{DISTRIBUTION}

Known only from Grand Cayman Island.

\section{REMARKS}

We tentatively place the new species in Proceraea, even though several of its morphological features are not found in any other member of the genus, including the trepan teeth being distributed in one single ring rather than two, and the dorsal cirri alternating in length rather than being equally long. The new species is however without any doubt a member of the tribe Procerini, as it has cirrophores only on the tentacular and first dorsal cirri, and thick, distally denticulated bayonet chaetae, which are morphological characters not found in either the tribe Autolytini or in the genus Epigamia. As there is no other genus described in Procerini that fits the new species better, and rather than describing a new genus for it, we prefer to place it in Proceraea for the time being, while waiting for molecular data to verify its phylogenetic position in Autolytinae. Among the taxa in Proceraea as well as in Procerini, P. janetae sp. nov. is unique in its trepan structure, its type of cirri alternation, with short cylindrical cirri alternating with longer swollen, egg-shaped ones, and in its colour pattern which is not found in any other described member of the Autolytinae.

\section{Behaviour}

We first observed and photographed $P$. janetae sp. nov. on a Solitary Disc coral, Scolymia cubensis (Milne Edwards \& Haime, 1849). However, this was the only finding on this coral, whereas all remaining specimens have always been found on Montastrea cavernosa. Since first observed, we have seen the worms on virtually all dives done in the area. We observed the worms to move from the areas surrounding the $M$. cavernosa colonies to the surface of the coral (Figure $5 \mathrm{~A}-\mathrm{C}$ ). The worms are very shy and their progress towards the coral may be easily disturbed, for instance, by the bright flashes of an underwater light variety used for photography; a specimen distressed just when emerging from the surrounding substrate immediate reacted and moved back into the substrate (Figure 5D). However, after some time, the worm crawled again towards the coral.

Once on the coral, the worms crawl among the polyps (Figure $1 \mathrm{~A}-\mathrm{D}$, Supplementary Video) until reaching the proximity of a polyp (Figure 6A-D). Then, they introduce their anterior end through the oral opening of the polyp (Figure $7 \mathrm{~A}-\mathrm{D}$ ) and appear to start feeding inside their gastral cavity. After feeding for some minutes, they remove their anterior end from the polyp's gastral cavity and start moving back towards the surrounding substrate (Figure 8A-D), where they disappear and remain hidden until the next expedition to the coral colony. All worms collected in this paper, except one, were actively feeding on polyps of $M$. cavernosa. The lone one was travelling across a colony of the same coral species when captured. When feeding, they are not easily disturbed by external stimuli (such as waving water by hand or by flashing lights).

The feeding behaviour of $P$. janetae sp. nov. closely resembles that of a small snail, Coralliophila caribbea Abbott, 1958 (Martin et al., 2014). The snails remain outside the same colonies of $M$. cavernosa where the polychaetes were found, and also were observed to feed by introducing the proboscis through the polyp's oral opening (Figure 9A, B).

\section{DISCUSSIDN}

Syllids live frequently in or on colonial organisms such as hydroids or bryozoans, as well as on massive benthic organisms such as sponges, and so it is often assumed that they can feed directly on them (Giangrande et al., 2000; Lattig \& Martin, 2009, 2011). Autolytines in particular usually live in close relationship with cnidarians, most commonly hydroids, and it has been postulated that they may feed on polyps (either directly on their tissues or by sucking their gastric fluids) or on tentacles and/or the upper portion of the hydrants (Okada, 1928; Giangrande et al., 2000). In all syllids, the proventricle creates a negative pressure through muscular movements causing the pharynx to become a powerful sucking tool, and this is particularly true for the autolytines, who have a very long and convoluted pharynx (Nygren, 2004). Accordingly, they are pharyngeal feeders using the trepan to scratch or pierce the tissues of their selected colonial preys (Giangrande etal., 2000). 

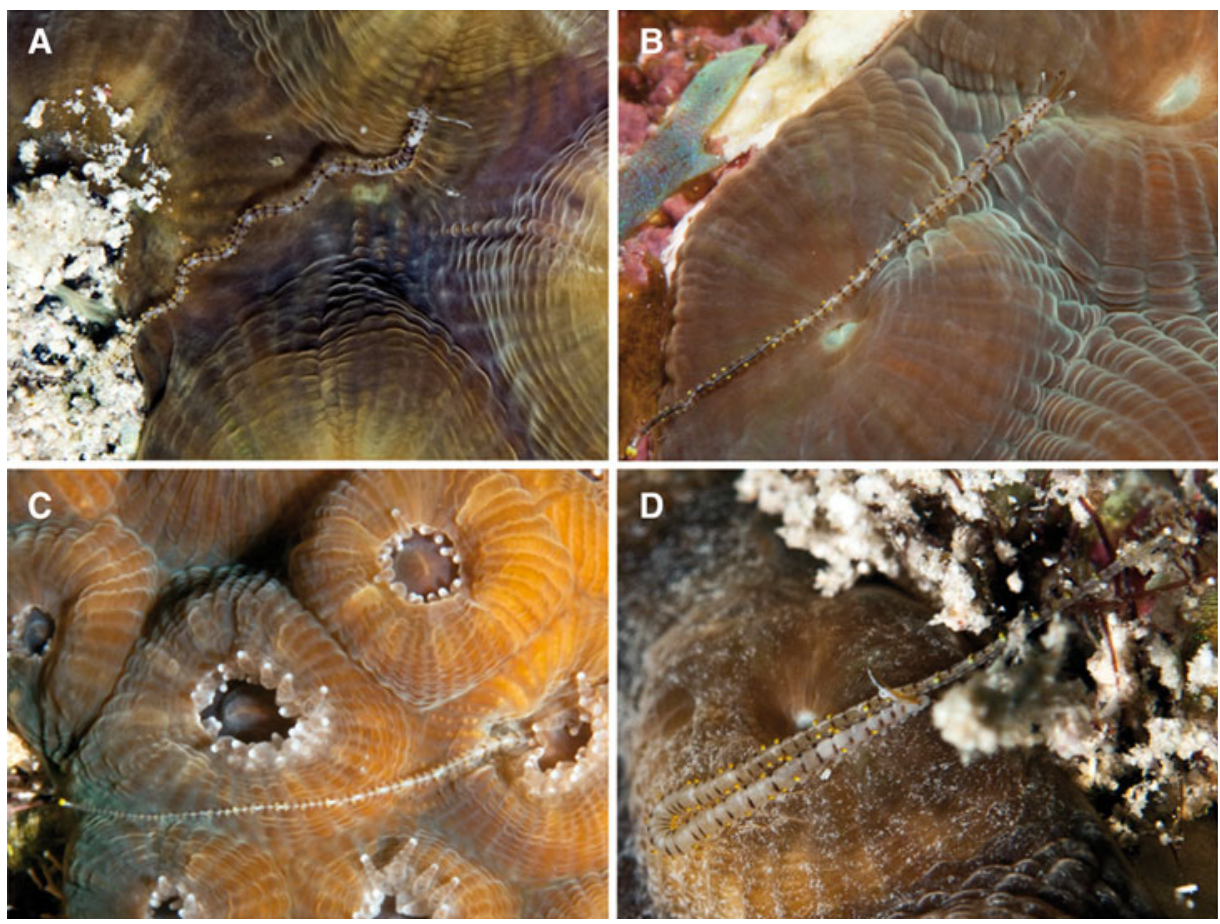

Fig. 5. Proceraea janetae sp. nov. (A-C) Examples of specimens moving from the surrounding substrate towards the coral Montastrea cavernosa. (D) Specimen returning to the substrate after being disturbed by light flashes.

Autolytines are carnivorous, as confirmed by direct observations (e.g. Allen, 1921; Okada, 1928; Hamond, 1969). Most species inhabit hyaline mucous tubes attached to the hydroid colony stem. These tubes are either built by the worm or induced by the worm to be built by the host colony. Such associations are, in some cases, highly specific (Nygren, 2004). However, only a few of them have been confirmed as symbiotic. Most are parasitic (Martin \& Britayev, 1998), such as Proceraea rzhavsky (Britayev \& San Martín, 2001) (but see Nygren, 2004 for a taxonomic discussion on that name) infesting the thecae of Abietinaria turgida (Clark, 1877) (Britayev et al., 1998; Britayev \& San Martín, 2001). The other known parasitic autolytine, Proceraea penetrans (Wright \& Woodwick, 1977), is found inside galls induced
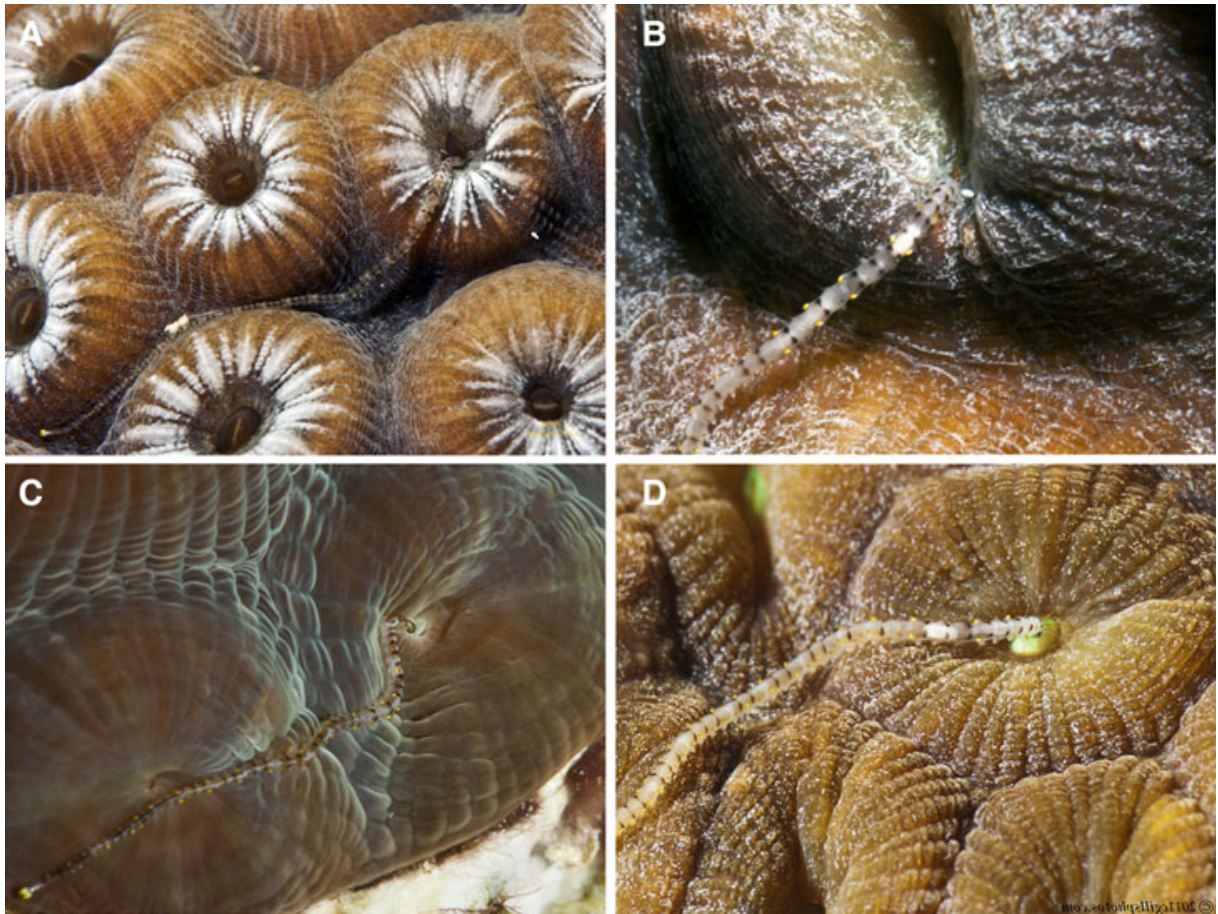

Fig. 6. Proceraea janetae sp. nov. (A-D) Examples of specimens approaching the polyps of Montastrea cavernosa for feeding. 

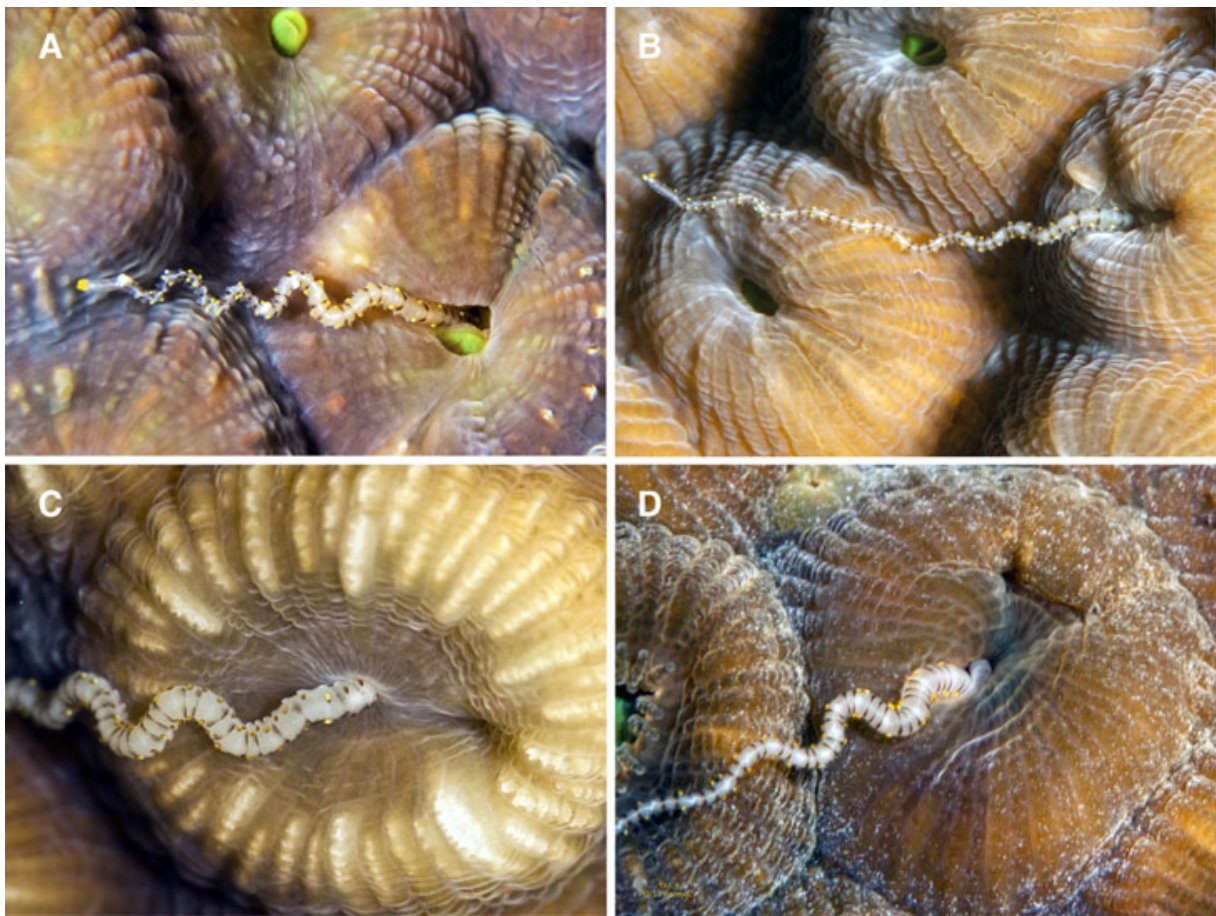

Fig. 7. Proceraea janetae sp. nov. (A-D) Examples of specimens with the anterior end introduced into the gastral cavity of closed polyps of Montastrea cavernosa.

in the tissues of its host hydrocoral, Stylaster californicus (Verrill, 1866); however, no indication of its feeding habits has been reported from the original description to date.

Proceraea janetae sp. nov. depends on the scleractinian coral $M$. cavernosa for feeding. Nevertheless it does not live attached to its prey, as happens with those autolytines related with hydroids. In turn, it inhabits the substrate surrounding the coral colonies and only moves towards the corals for feeding, then immediately leaves them. To the best of our knowledge, such behaviour had never been previously reported for another autolytine, or even for another syllid. However, it is possible that the absence of reports is due to the lack of field observations, not the actual absence of such a behaviour.
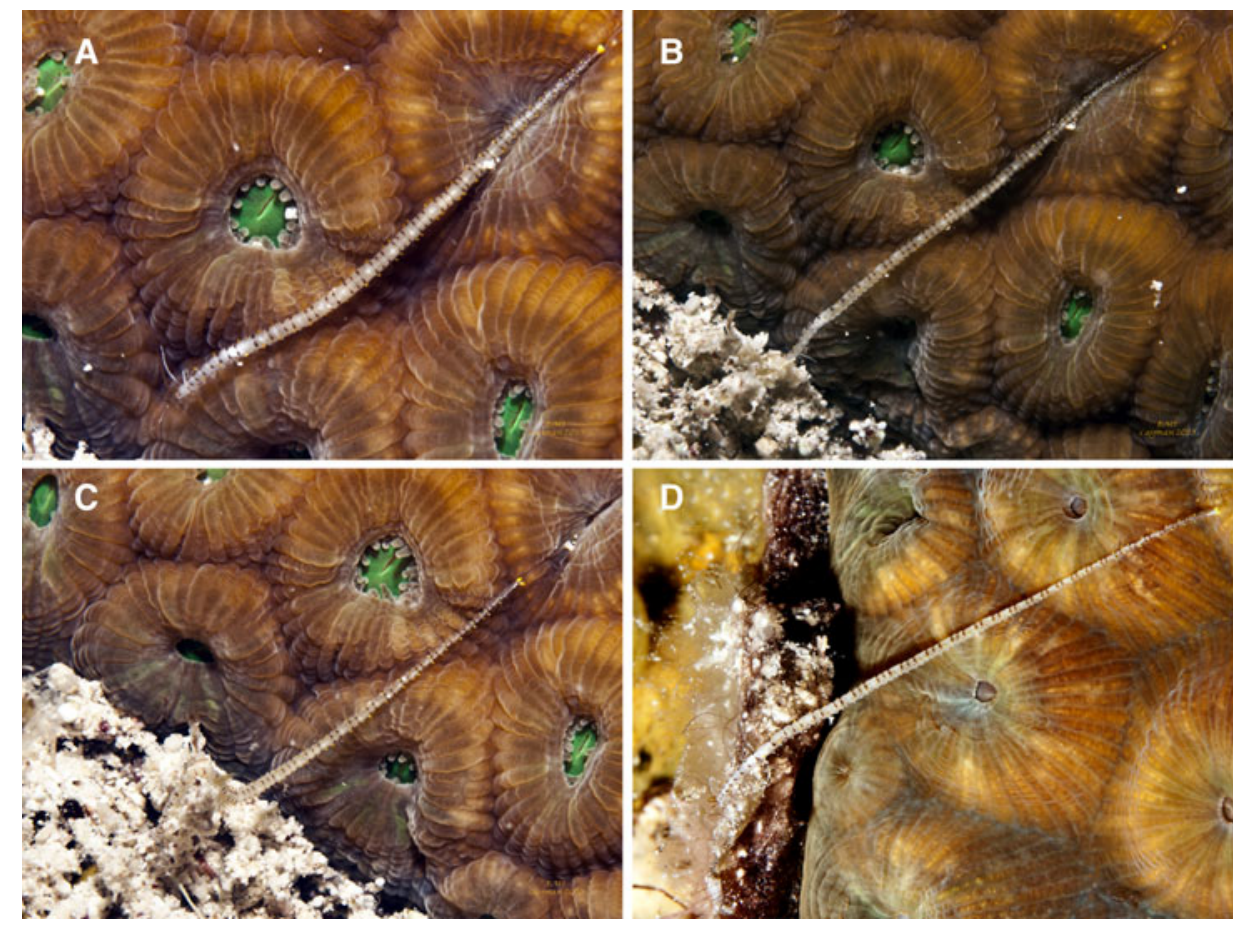

Fig. 8. Proceraea janetae sp. nov. (A-D) Examples of specimens leaving the colonies of Montastrea cavernosa after feeding. (A-C) Successive images corresponding to the same specimen and episode. 

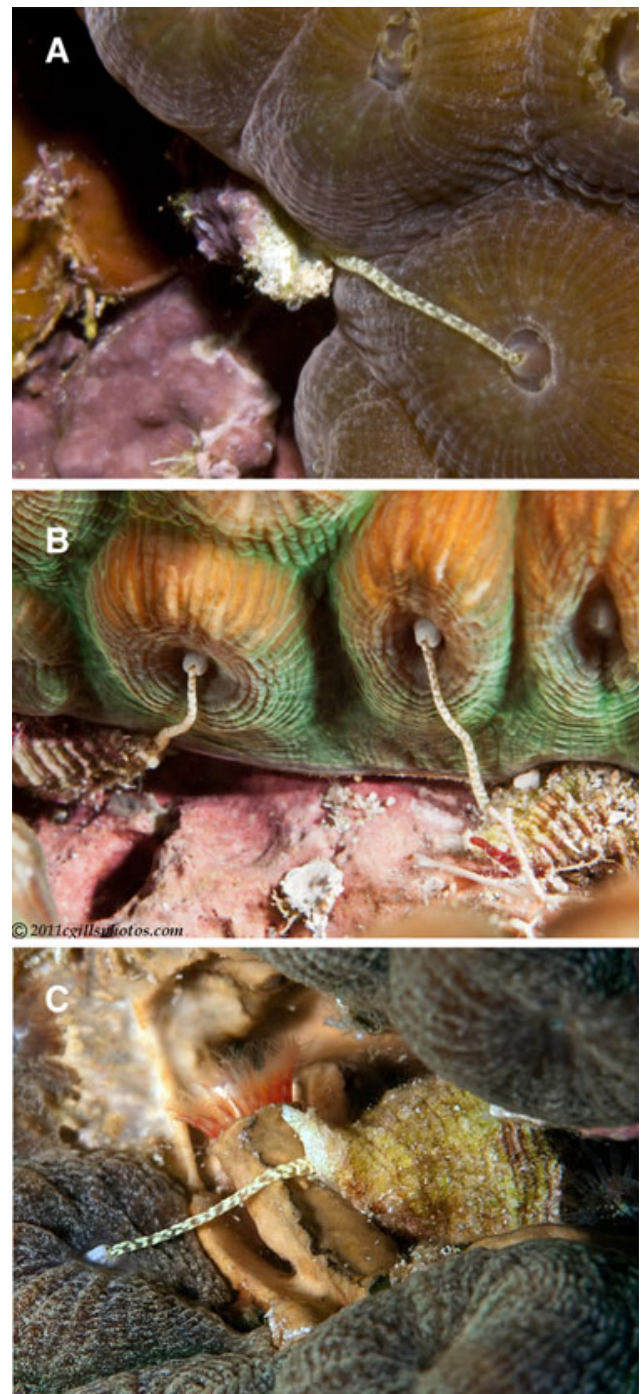

Fig. 9. (A-C) Coralliophila caribbea feeding on polyps of the same colonies where Proceraea janetae sp. nov. was collected.

Some cnidarian-associated syllids, such as Haplosyllis chamaeleon (Laubier, 1960) living on Paramuricea species (Martin et al., 2002; Lattig \& Martin, 2009), feed also by introducing the anterior end inside the gastral cavity of the polyps of its hosts. However, this species is an obligate symbiont, living always on the surface of its gorgonian hosts (Martin \& Britayev, 1998; Martin et al., 2002), while P. janetae sp. nov. appears to be free-living, at least during part of its life. Another gorgonian symbiont, Haplosyllis anthogorgicola Utinomi, 1956, apparently feeds in a similar way to $P$. janetae sp. nov., approaching the host polyps to feed, then moving away. However, as in the case of $H$. chamaeleon, they remain on the host gorgonian. In fact, they live inside galleries excavated in the soft tissues of the host and emerge through tubes opening in the vicinity of the polyps, which are induced in the host tissues (Martin et al., 2002). As for the symbiotic species of Haplosyllis, in light of our observations we cannot assess whether $P$. janetae sp. nov. feeds on the coral tissues or on the food captured by the polyps and remaining inside their gastral cavity. It may also be possible that they could feed on the coral eggs, which are stored inside the polyps before being released; however, this could not be checked as the sampling period did not correspond with the reproductive period of the coral (H.R. Lasker, The State University of New York at Buffalo, personal communication).

Curiously, the feeding behaviour of $P$. janetae sp. nov. resembles that of the corallivorous gastropod C. caribbea (Martin et al., 2014). In this case, a 'prudent feeding' strategy was proposed for this species, in which the exploited resources could be zooxanthellae translocated from the interior of the colony towards the exploited coral areas. These translocated zooxanthellae may function as energy reserves (Oren et al., 1998), which may occur in diferent corals and thus might be used as a source of food by many other species feeding on scleractinian corals (Oren et al., 1998; Martin et al., 2014). Therefore, these coral associates could be closer to true parasites than to specialized predators (Martin et al., 2014).

The feeding strategy of $P$. janetae sp. nov., however, differs from that of C. caribbea in their position with respect to the coral. The snails had only the proboscis directed towards the polyps, while the polychaete was able to move across the coral surface without incident. We postulate that the snails could be avoiding being attacked by the coral, whereas the polychaetes apparently demonstrate a further degree of adaptation. This may either be chemically based, e.g. similar to that of the clownfish and their anemone partners, or just behavioural, e.g. with body movements mimicking the tentacle movements to avoid attack, as in the case of Neanthes fucata (Savigny in Lamarck, 1818), which mimics the mandible movements of its host hermit crab to avoid attacks while stealing food pieces directly from the crab's jaws (Goerke, 1971a, b). We have no evidence to support such behaviour. Additional studies would be required to further elucidate these interesting questions, which may have relevant implications toward classifying the mode of life of $P$. janetae sp. nov. as a specialized predator or as a parasite.

Recently, the sylline syllid Alcyonosyllis hinterkircheri Glasby \& Aguado, 2009 has also been reported as living in association with a scleractinian coral, in this case Goniopora cf. stokesi Milne Edwards \& Haime, 1851. Living worms appear to be well camouflaged at the bases of the long polyps of the host and their colour pattern and shape mimics that of the coral. Only when the polyps are withdrawn can the polychaetes be easily distinguished. Moreover, this species lives always on its host scleractinian coral and so it was considered to be a symbiont, like all remaining congeneric species, which are associated with octocorals (Glasby \& Aguado, 2009). However, no descriptions of its feeding behaviour have been reported. Conversely, the highly characteristic colour pattern of $P$. janetae sp. nov. seems to be closer to an aposematic colouring than to a camouflage one. Whether this colour pattern allows this species to remain hidden on the substrate surrounding the corals or serves as a protection from predation while crawling and feeding on their coral preys/hosts (or both) remains open to further studies.

To the best of our knowledge, there has been only one species of polychaete whose behaviour as a coral feeder has been previously demonstrated, the amphinomid Hermodice carunculata (Pallas, 1766) (Robertson, 1970; Ott \& Lewis, 1972; Wolf \& Nugues, 2013). However, this species also feeds on other cnidarians such as gorgonians (Vreeland \& Lasker, 1989) and it is clearly a predator, not a parasite. Proceraea janetae sp. nov is thus the second polychaete, and the first syllid, known to feed on scleractinian corals. To some extent, its feeding mode resembles those of the symbiotic 
(i.e. kleptoparasitic) species of Haplosyllis living in association with gorgonians (Martin et al., 2002). Thus, we suggest that its association with the coral might be either a temporary parasitism (e.g. like a 'coral mosquito'), as supported by its characteristic colour pattern, or an intermediate step in the evolution from a specialized predator towards an obligate symbiont.

The species of Coralliophila certainly contribute to coral reef destructive processes, especially in the Caribbean (Ward, 1965; Johnston, 2012). Being corallivorous too, the new polychaete species described here could also eventually contribute to this destruction, particularly if the delicate equillibrium allowing coral reefs to survive is altered under the currently existing pressure of both natural and anthropogenic stressors. Knowledge on the existence of new corallivorous species and their relationships with their coral preys/hosts may contribute to the implementation of effective conservation and management strategies as well as to the prediction of how coral reefs will respond to further perturbations in the future.

\section{ACKNDWLEDGEMENTS}

We would like to thank the Cayman Islands Department of Environment and the Cayman Environmental Centre for kindly allowing us to collect the specimens for our study and, particularly, to Timothy J. Austin, Deputy Director of the Department for being so helpful during that process. The authors would also like to thank Diane Randolph, of West Palm Beach Florida, USA, for her video skills and footage of $P$. janetae sp. nov.

\section{FINANCIAL SUPPDRT}

The study has been partly financed by the BENTHOMICS project (CTM2010-22218-Co2-01) funded by the Spanish Plan Nacional de Investigación Científica, Desarrollo e Innovación Tecnológica. This paper is a contribution of DM and JG to the Consolidated Research Group 2014SGR120 of the Generalitat of Catalunya.

\section{Supplementary materials and methods}

The supplementary material for this article can be found at http://www.journals.cambridge.org/MBI

\section{REFERENCES}

Abbott R.T. (1958) Marine mollusks of Grand Cayman Island, British West Indies. Monographs of the Academy of Natural Sciences of Philadelphia 11, 1-138.

Aguado M.T. and San Martín G. (2009) Phylogeny of Syllidae (Polychaeta) based on morphological data. Zoologica Scripta 38, $379-402$.

Allen E.J. (1921) Regeneration and reproduction of the syllid Procerastea. Philosophical Transactions of the Royal Society of London 211, $131-177$.

Audouin J.V. and Milne-Edwards H. (1832) Classification des Annélides et description de celles qui habitent les côtes de la France. Annales des Sciences Naturelles, Paris 27, 337-347.
Britayev T.A. and San Martín G. (2001) Description and life-history traits of a new species of Proceraea with larvae infecting Abietinaria turgida (Polychaeta, Syllidae and Hydrozoa, Sertulariidae). Ophelia 54, $105-113$.

Britayev T.A., San Martín G. and Sheiko O. (1998) Symbiotic polychaetes Proceraea sp. (Polychaeta, Syllidae) and modification of hydrothecae in hydroid Abietinaria turgida (Hydrozoa, Sertullariidae). Zoologicheskii Zhurnal 77, 527-532.

Clark S.F. (1877) Report on the hydroids collected on the coast of Alaska and the Aleutian Islands, by W.H. Dall, U.S. Coast Survey, and party, from 1871 to 1874 inclusive. Proceedings of the Academy of Natural Sciences of Philadelphia 28, 209-238.

Dales R.P. (1962) The polychaete stomodeum and the inter-relationships of the families of Polychaeta. Proceedings of the Zoological Society of London 139, 389-428.

Ehlers E. (1864) Die Bortenwü¥rmer (Annelida Chaetopoda) nach systematischen und anatomischen Untersuchungen dargestellt. Volume 1. Leipzig: Wilhelm Engelmann.

Fauchald K. and Jumars P.A. (1979) The diet of worms: a study of polychaete feeding guilds. Oceanography and Marine Biology: an Annual Review 17, 193-284.

Fischer A., Mewes K. and Franke H.D. (1992) Stolonization and mating behavior of Autolytus prolifer (Polychaeta). Göttingen: Institute of the Scientific Film.

Franke H.D. (1999) Reproduction of the Syllidae (Annelida: Polychaeta). In Reproductive strategies and developmental patterns in annelids. Hydrobiologia 402, 39-55.

Genzano G.N. and San Martín G. (2002) Association between the polychaete Procerastea halleziana (Polychaeta: Syllidae: Autolytinae) and the hydroid Tubularia crocea (Cnidaria: Hydrozoa) from the Mar del Plata intertidal zone, Argentina. Cahiers de Biologie Marine 43, 165-170.

Giangrande A., Licciano M. and Pagliara P. (2000) The diversity of diets in Syllidae (Annelida: Polychaeta). Cahiers de Biologie Marine $41,55-65$.

Gidholm L. (1967) A revision of Autolytinae (Syllidae, Polychaeta) with special reference to Scandinavian species, and with notes on external and internal morphology, reproduction and ecology. Arkiv för Zoologi 19, 157-213.

Glasby C.J. and Aguado M.T. (2009) A new species and new records of the anthozoan commensal genus Alcyonosyllis (Polychaeta: Syllidae). The Beagle, Records of the Museums and Art Galleries of the Northern Territory 25, 55-63.

Goerke H. (1971a) C 1462 Commensalism of Nereis fucata (Polychaeta). Göttingen, Germany: Institut für den Wissenschaftlichen Film.

Goerke H. (1971b) Nereis fucata (Polychaeta, Nereidae) als kommensale von Eupagurus bernhardus (Crustacea, Decapoda) entwicklung einer population und verhalten der art. Veröffentlichungen des Instituts für Meeresforschung in Bremerhaven 13, 79-81.

Grube A.E. (1850) Die Familien der Anneliden. Archiv für Naturgeschichte, Berlin 16, 249-364.

Hamond R. (1969) On the preferred foods of some autolytoids (Polychaeta, Syllidae). Cahiers de Biologie Marine 10, 439-445.

Johnston L. (2012) Evolutionary ecology of the corallivorous gastropod, Coralliophila abbreviata: Implications for imperiled Caribbean corals. Open access dissertations. Paper 767. University of Miami, Miami.

Lamarck J.B. (1809) Philosophie Zoologique, ou exposition des considérations relatives à l'histoire naturelle des Animaux; à la diversité de leur organisation et des facultés qu'ils en obtiennent; aux causes physiques 
qui maintiennent en eux la vie et donnent lieu aux mouvements qu'ils exécutent; enfin, à celles qui produisent, les unes le sentiment, et les autres l'intelligence de ceux qui en sont doués. Paris: Dentu.

Lamarck J.B. (1818) Histoire naturelle des Animaux sans Vertèbres, présentant les caractères généraux et particuliers de ces animaux, leur distribution, leurs classes, leurs familles, leurs genres, et la citation des principales espèces qui s'y rapportent; précédée d'une Introduction offrant la détermination des caractères essentiels de l'animal, sa distinction du végétal et des autres corps naturels, enfin, l'exposition des principes fondamentaux de la zoologie, Volume 5. Paris: Déterville \& Verdière.

Langerhans P. (1879) Die Wurmfauna von Madeira. Zeitschrift für Wissenschaftliche Zoologie 32, 513-592.

Lattig P. and Martin D. (2009) A taxonomic revision of the genus Haplosyllis Langerhans, 1887 (Polychaeta: Syllidae: Syllinae). Zootaxa 2220, 1-40.

Lattig P. and Martin D. (2011) Sponge-associated Haplosyllis (Polychaeta: Syllidae: Syllinae) from the Caribbean Sea, with the description of four new species. Scientia Marina 75, 733-758.

Laubier L. (1960) Une nouvelle sous-espèce de Syllidien: Haplosyllis depressa Augener ssp. nov. chamaeleon, ectoparasite sur l'octocoralliaire Muricea chamaeleon Von Koch. Vie et Milieu 11, 75-87.

Linnaeus C. (1767) Systema Naturae per Regna Tria Naturae, Editio Duodecima, Reformata, Tomus I, Pars II. Regnum Animale. Stockholm: Laurentii Salvii.

Martin D. and Britayev T.A. (1998) Symbiotic polychaetes: review of known species. Oceanography and Marine Biology: an Annual Review 36, 217-340.

Martin D., Gil J., Abgarian C., Evans E., Turner E.M. Jr and Nygren A (2014) Coralliophila from Grand Cayman: specialized coral predator or parasite? Coral Reefs, Online First. doi: 10.1007/soo338014-1190x.

Martin D., Núñez J., Riera R. and Gil J. (2002) On the association between Haplosyllis (Polychaeta, Syllidae) and gorgonians (Cnidaria, Octocorallaria), with a description of a new species. Biological Journal of the Linnean Society 77, 455-477.

Milne Edwards H. and Haime J. (1851) Recherches sur les polypiers. Septième mémoire. Monographie des Poritides. Annales des Sciences Naturelles, Série 3, Zoologie 16, 21-70, plate 21.

Nygren A. (2004) Revision of Autolytinae (Syllidae: Polychaeta). Zootaxa $680,1-314$.

Nygren A. and Pleijel F. (2007) A new species of Myrianida (Syllidae, Polychaeta) from Belize. Zootaxa 1595, 17-29.

Nygren A. and Pleijel F. (2010) Redescription of Imajimaea draculai - a rare syllid polychaete associated with the sea pen Funiculina quadrangularis. Journal of the Marine Biological Association of the United Kingdom 90, 1441-1448.

Nygren A. and Sundberg P. (2003) Phylogeny and evolution of reproductive modes in Autolytinae (Syllidae, Annelida). Molecular Phylogenetics and Evolution 29, 235-249.
Nygren A., Sundkvist T., Mikac B. and Pleijel F. (2010) Two new and two poorly known autolytines (Polychaeta: Syllidae) from Madeira and the Mediterranean Sea. Zootaxa 2640, 35-52.

Okada Y.K. (1928) Feeding organs and feeding habits of Autolytus edwardsi St. Joseph. Quarterly Journal of Microscopical Science, London 72, 219-245.

Oren U., Brickner I. and Loya Y. (1998) Prudent sessile feeding by the corallivore snail Coralliophila violacea on coral energy sinks. Proceedings of the Royal Society of London, Series B: Biological Sciences 265, 2051-2055

Ott B. and Lewis J.B. (1972) The importance of the gastropod Coralliophila abbreviata (Lamarck) and the polychaete Hermodice carunculata (Pallas) as coral reef predators. Canadian Journal of Zoology 50, $1651-1656$.

Pallas P.S. (1766) Miscellanea Zoologica, quibus noví imprimis atque obscurí animalium species describuntur et observationibus iconibusque illustrantur. Hagí Comitum: Petrum van Cleef.

Robertson R. (1970) Review of the predators and parasites of stony corals, with special reference to symbiotic prosobranch gastropods. Pacific Science. University of Hawai'i Press 24, 43-54.

Utinomi H. (1956) On the so-called 'Umi-Utiwa' a peculiar flabellate gorgonacean, with notes on a syllidean polychaete commensal. Publications of the Seto Marine Biological Laboratory 5, 243-250.

Verrill A.E. (1866) Synopsis of the polyps and corals of the North Pacific Exploring Expedition, under Commodore C. Ringgold and Captain John Rogers, U.S.N., from 1853 to 1856 . Collected by Dr. Wm. Stimpson, naturalist to the expedition. With descriptions of some additional species from the west coast of North America. Pt. 3 : Madreporaria. Proceedings of the Essex Institute 5, 17-50, plates $11-12$.

Vreeland H.V. and Lasker H.R. (1989) Selective feeding of the polychaete Hermodice carunculata Pallas on Caribbean gorgonians. Journal of Experimental Marine Biology and Ecology 129, 265-277.

Ward J. (1965) The digestive tract and its relation to feeding habits in the stenoglossan prosobranch Coralliophila abbreviata (Lamark). Canadian Journal of Zoology 43, 447-464.

Wolf A.T. and Nugues M.M. (2013) Predation on coral settlers by the corallivorous fireworm Hermodice carunculata. Coral Reefs 32 , $227-231$.

and

Wright J.D. and Woodwick K.H. (1977) A new species of Autolytus (Polychaeta: Syllidae) commensal on a Californian hydrocoral. Bulletin of the Southern California Academy of Sciences 76, 42-48.

\section{Correspondence should be addressed to:}

D. Martin

Centre d'Estudis Avançats de Blanes (CEAB-CSIC), Carrer d'Accés a la Cala Sant Francesc 14, 17300 Blanes (Girona), Catalunya, Spain. email: dani@ceab.cisc.es 